\title{
In vitro Antibacterial Activity of Foeniculum vulgare Seed Extract Khan NT*
}

Department of Biotechnology, Balochistan University of Information Technology Engineering and Management Sciences (BUITEMS), Quetta, Pakistan

\begin{abstract}
Foeniculum vulgare (Apiaceae) is a popular plant with valuable medicinal and culinary importance. It is mostly used in the treatment of ailments associated with digestive and respiratory systems. Besides its fruit are dry seeds which is used as flavoring agent for meat, fish and beverages. Phytoconstituents of $F$. vulgare seed extracts such as phenols and aromatic derivatives possess different physiochemical properties including competence to inhibit the growth of certain bacteria. Thus this study was conducted to determine the antibacterial property of Foeniculum vulgare seed extract against a variety of pathogenic bacteria.
\end{abstract}

Keywords: Anti-bacterial; Foeniculum vulgare; Phytoconstituents

\section{Introduction}

Foeniculum vulgare is a periodic herb with potent medicinal importance belonging to the family Umbelliferae (Apiaceae). In English it is known by the name of Fennel, Fenouil in French, Shmr (Razianaj) in Arabic and Razianeh in Persian. It is an herbaceous and aromatic plant, with a height of 1 to $2 \mathrm{~m}$, grows in many parts of Europe, the Mediterranean, and Asia. Fennel is a perennial herb with stems grooved, intermittent leaves, often combined with dark green, fluffy with a blade divided into thin pieces, petiole with sheath; flowers are usually bisexual, regular or irregular, with yellow umbrella in the form of oval beads $[1,2]$. Fennel has small seed with a length of about $8 \mathrm{~mm}$ and a width of $3 \mathrm{~mm}$ with an aromatic odor and sweet taste. Fennel seeds are narrow, long, cylindrical appearance and dimensions vary depending on plant growth. The crack groove light green surface $[3,4]$. The water content of fennel seed is $6.3 \%$ water, fat $10 \%$, protein $9.5 \%$, minerals $13.4 \%$, fibers $18.5 \%$ and carbohydrates $42.3 \%[5,6]$. The oil extracted from Foeniculum vulgare seeds showed the capability to inhibit bacterial growth including Escherichia coli, Bacillus megaterium and Staphylococcus aureus [7], Listeria monocytogenes and S. aureus $[8,9]$. Its alcoholic and aqueous extracts are known to effective towards Campylobacter jejuni and Helicobacter pylori [10]. It was revealed in another study that Foeniculum vulgare seed extracts also inhibits the growth of multidrug resistant bacteria such as Acinetobacter baumannii. The aromatic secondary metabolites present in the extracts were mainly responsible for this activity [11]. The main purpose of this study was to evaluate the antibacterial activity of Foeniculum vulgare against a number of disease causing bacteria.

\section{Materials and Methods}

\section{Plant extraction}

$100 \mathrm{~g}$ of dried Foeniculum vulgare seeds were bought from a local shop in satellite town Quetta and milled to form a course powder and then extracted with methanol $(500 \mathrm{ml})$. The aqueous extract was prepared by boiling $10 \mathrm{~g}$ of dried ground seed in $20 \mathrm{ml}$ distilled water for $2 \mathrm{~h}$.

\section{Antibacterial activity evaluation by disc diffusion assay}

Antibacterial activity of aqueous and methanolic extract was individually tested against a number of pathogenic bacteria by dis diffusion method. Using $1 \mathrm{~cm}$ sterilized discs prepared from Whatman's filter paper no.1, impregnated with alcoholic and aqueous seed extracts on nutrient agar incubated for $48 \mathrm{hrs}$ at $37^{\circ} \mathrm{C}$. Test species of bacteria includes Bacillus subtilis, Staphylococcus aureus, Escherichia coli, Klebsiella pneumoniae, Pseudomonas aeruginosa, Bacillus cereus, Bacillus pumilus, Bacillus megaterium, Shigella dysenteriae, Shigella shiga, Salmonella typhi, Shigella boydii, Micrococcus lutus, Pseudomonos pupida, Pseudomonos syringae, Salmonella typhimurium, Shigella dysenteriae, Staphylococcus albus, Streptococcus haemolyticus and Agrobacterium tumefaciens. Presence or absence of inhibition zone around the impregnated discs indicated the antibacterial property of the extracts. Nutrient agar plates with discs impregnated with autoclaved distilled water was taken as control in all experiments.

\section{Results}

Foeniculum vulgare seed extracts were evaluated for their antibacterial activity (Table 1).

\section{Discussion}

The antifungal activity of different Foeniculum vulgare seed extracts expressed as the presence or absence of inhibition zone is summarized in Table 1. Methanolic extract of Foeniculum vulgare seeds showed activity against Bacillus subtilis, Staphylococcus aureus, Escherichia coli, and Klebsiella pneumoniae but no activity against Pseudomonas aeruginosa, Bacillus cereus, Bacillus pumilus, Bacillus megaterium, Shigella dysenteriae, Shigella shiga, Salmonella typhi, Shigella boydii, Micrococcus lutus, Pseudomonos pupida, Pseudomonos syringae, Salmonella typhimurium, Shigella dysenteriae, Staphylococcus albus, Streptococcus haemolyticus and Agrobacterium tumifaciens. However its aqueous extract found to be more effective in terms of its antibacterial activity. As the obtained result clearly revealed that aqueous extract inhibited the growth of a number of bacterial species such as Pseudomonos pupida, Pseudomonos syringae, Shigella dysenteriae, Staphylococcus albus, Streptococcus haemolyticus, Staphylococcus aureus, Bacillus subtilis, Bacillus pumilus, Bacillus

*Corresponding author: Khan NT, Department of Biotechnology, Faculty of Life Sciences and Informatics, Balochistan University of Information Technology Engineering and Management Sciences (BUITEMS), Quetta, Pakistan, Tel: 03368164903; E-mail: nidatabassumkhan@yahoo.com

Received July 31, 2017; Accepted August 04, 2017; Published August 11, 2017

Citation: Khan NT (2017) In vitro Antibacterial Activity of Foeniculum vulgare Seed Extract. Agrotechnology 6: 162. doi: 10.4172/2168-9881.1000162

Copyright: (c) 2017 Khan NT. This is an open-access article distributed under the terms of the Creative Commons Attribution License, which permits unrestricted use, distribution, and reproduction in any medium, provided the original author and source are credited. 


\begin{tabular}{|c|c|c|c|}
\hline S. No. & Names & $\begin{array}{c}\text { Aqueous extract } \\
\text { inhibition zone }\end{array}$ & $\begin{array}{c}\text { Methanolic } \\
\text { extract } \\
\text { inhibition zone }\end{array}$ \\
\hline 1. & Escherichia coli & - & + \\
\hline 2. & Pseudomonos pupida & + & - \\
\hline 3. & Pseudomonos syringae & + & - \\
\hline 4. & Salmonella typhimurium & - & - \\
\hline 6. & Staphylococcus albus & + & - \\
\hline 7. & Streptococcus haemolyticus & + & - \\
\hline 8. & Agrobacterium tumefaciens & - & - \\
\hline 9. & Micrococcus lutus & - & - \\
\hline 10. & Staphylococcus aureus & + & + \\
\hline 11. & Bacillus subtilis & + & + \\
\hline 12. & Pseudomonas aeruginosa & - & - \\
\hline 13. & Bacillus cereus & - & - \\
\hline 14. & Bacillus pumilus & + & - \\
\hline 15. & Bacillus megaterium & + & - \\
\hline 16. & Shigella dysenteriae & + & - \\
\hline 17. & Shigella shiga & + & - \\
\hline 18. & Klebsiella pneumoniae & + & + \\
\hline 19. & Salmonella typhi & - & - \\
\hline 20. & Shigella boydii & - & - \\
\hline$(+)$ Indicates the inhibition of the fungal growth & & \\
\hline$(-)$ Indicates no inhibition of fungal growth & & \\
\hline & & + & \\
\hline
\end{tabular}

Table 1: Observed inhibition zone.

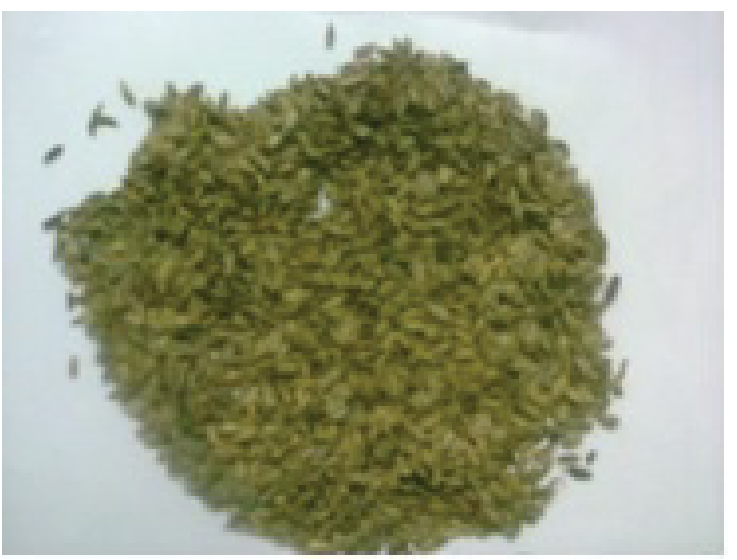

Figure 1: Foeniculum vulgare seeds.

megaterium, Shigella shiga and Klebsiella pneumoniae. Bacillus subtilis was found to be sensitive to the aqueous and methanolic extracts of the fennel seeds. The high antibacterial activity of fennel aqueous seed extracts is probably due to the high concentration of secondary metabolites that are very much soluble in water $[12,13]$. The aqueous extract of fennel seed showed broad antibacterial spectrum against a wide range of gram negative and gram positive bacteria [14]. This is due to the presence of compounds such as, linoleic acid, undecanal, 1, 3-benzenediol, oleic acid and 2, 4-undecadienal in the extract. It is reported that fennel seed extract contain 5-hydroxy-furanocoumarin which contributes in antimicrobial property of this plant [15].

\section{Conclusion}

Available researches have shown that extracts of fennel possess pharmacological properties such as antibacterial activity. Medicinal properties of the plant are due to its different chemical compounds. Among the various compounds found in fennel plant essence and phenolic compounds are considered as the most important and most active compounds of it. The fennel bioactive molecules can be used for different drug production and for the synthesis of antimicrobial agents

\section{References}

1. Pourabbas S, Kesmati M, Rasekh A (2011) Study of the the anxiolytic effects of fennel and possible roles of both gabaergic system and estrogen receptors in these effects in adult female rat. Physiol Pharmacol 15: 134-143.

2. Bernath J, Nemeth E, Kattaa A, Hethelyi E (1996) Morphological and chemical evaluation of fennel (Foeniculum vulgare Mill.) populations of different origin. $J$ Essent Oil Res 8: 247-253.

3. Ahmadi A, Nasiri Nejad F, Parivar K (2007) Effect of aqueous extract of the aerial part of the Ruta graveolens on the spermatogenesis of immature Balb/C mice. Razi J Med Sci 14: 13-20.

4. Moura LS, Carvalho RN, Stefanini MB, Ming LC, Meireles MAA (2005) Supercritical fluid extraction from fennel (Foeniculum vulgare): global yield, composition and kinetic data. J Supercrit Fluids 35: 212-219.

5. Rather MA, Dar BA, Sofi SN, Bhat BA, Qurishi MA (2016) Foeniculum vulgare: A comprehensive review of its traditional use, phytochemistry, pharmacology, and safety. Arab J Chem 9: 1574-1583.

6. Miguel MG, Cruz C, Faleiro L, Simoes M, Figueiredo AC, et al. (2010) Foeniculum vulgare essential oils: chemical composition, antioxidant and antimicrobial activities. Nat Prod Commun 5: 319-328.

7. Mohsenzadeh M (2007) Evaluation of antibacterial activity of selected Iranian essential oils against Staphylococcus aureus and Escherichia coli in nutrient broth medium. Pak J Biol Sci 10: 3693-3697.

8. Dadalioglu I, Evrendilek GA (2004) Chemical compositions and antibacteria effects of essential oils of Turkish oregano (Origanum minutiflorum), bay laurel (Laurus nobilis), Spanish lavender (Lavandula stoechas L.), and fennel (Foeniculum vulgare) on common food borne pathogens. J Agric Food Chem 52: 8255-8260.

9. Cantore PL, lacobelli NS, Marco AD, Capasso F, Senatore F (2004) Antibacterial activity of Coriandrum sativum L. and Foeniculum vulgare Miller Var. vulgare (Miller). Essential oils. J Agric Food Chem 52: 7862-7866.

10. Mahady GB, Pendland SL, Stoia A, Hamill FA, Fabricant D, et al. (2005) In vitro susceptibility of Helicobacter pylori to botanical extracts used traditionally for the treatment of gastrointestinal disorders. Phytother Res 19: 988-991.

11. Kwon YS, Choi WG, Kim WJ, Kim WK, Kim MJ, et al. (2002) Antimicrobial constituents of Foeniculum vulgare. Arch Pharmacal Res 25: 154-157.

12. Parejo I, Jauregui $O$, Sanchez-Rabaneda F, Viladomat F, Bastida J, et al. (2004) Separation and in fennel (Foeniculum vulgare) using liquid chromatography-negative electrospray ionization tandem characterization of phenolic compounds mass spectrometry. J Agric Food Chem 52: 3679-3687.

13. Dusko BL, Comic L, Sukdolak S (2006) Antibacterial activity of some plants from family Apiaceae in relation to selected phytopathogenic bacteria. Kragujevac $\mathrm{J}$ Sci 28: 65-72.

14. Cwikla C, Schmidt K, Matthias A, Bone K, Lehmann R, et al. (2010) Investigations into the antibacterial activities of phytotherapeutics against Helicobacter pylori and Campylobacter jejuni. Phytother Res 24: 649-656.

15. Esquivel-Ferrino PC, Favela-Hernandez JMJ, Garza-Gonzalez E, Waksman N, Rios MY, et al. (2012) Ant mycobacterial activity of constituents from Foeniculum vulgare var. dulce grown in Mexico. Molecules 17: 8471-8482. 